\title{
PENERAPAN MODEL PEMBELAJARAN KOOPERATIF TIPE THINK PAIR SHARE (TPS) UNTUK MENINGKATKAN AKTIVITAS DAN KETUNTASAN BELAJAR SISWA
}

\author{
Euis Ani Arlinah ${ }^{\bowtie}$ \\ Public Middle School 1 Margahayu
}

\begin{abstract}
Info Artikel Abstrak
Sejarah Artikel: Disubmit: September 2021

Direvisi: Oktober 2021

Diterima: November 2021

\section{Keywords:}

Think Pair Share; Student Learning Completeness; Student Learning Activities

Ketidakmampuan sebagian besar siswa dalam memecahkan suatu permasalahan memperlihatkan bahwa siswa belum memahami konsep yang diajarkan guru dalam kegiatan pembelajaran, keterampilan memecahkan suatu permasalahan secara individu dan bekerjasama, siswa perlu diarahkan kepada suatu pemahaman, salah satunya dengan menentukan model pembelajaran, model pembelajaran kooperatif tipe Think Pair Share (TPS) merupakan sebuah model pembelajaran yang dapat meningkatkan efektivitas belajar psikomotorik siswa. Hasil penelitian menunjukkan bahwa : (a) sebagian besar siswa memberikan respon yang positif terhadap penerapan model pembelajaran kooperatif tipe TPS, (b) hasil observasi menunjukkan sebagian besar siswa dapat beraktivitas dalam proses pembelajaran, (c) hasil tes formatif dan tes sumatif menunjukkan bahwa siswa mengalami tingkat ketuntasan yang meningkat, (d) model pembelajaran kooperatif tipe TPS dapat meningkatkan aktivitas dan ketuntasan belajar siswa.
\end{abstract}

\begin{abstract}
The inability of most students to solve a problem shows that students do not understand the concepts taught by the teacher in learning activities, the skills to solve a problem individually and collaboratively, students need to be directed to an understanding, one of which is by determining the learning model, the cooperative learning model type Think Pair Share (TPS) is a learning model that can increase the effectiveness of students' psychomotor learning. The results showed that: (a) most of the students gave a positive response to the application of the TPS type cooperative learning model, (b) the results of observations showed that most of the students could be active in the learning process, (c) the results of the formative and summative tests showed that the students experience an increased level of completeness, (d) the TPS type cooperative learning model can increase student learning activities and mastery.
\end{abstract}

(C) 2021 Universitas Negeri Semarang

\begin{tabular}{lr}
\hline Alamat korespondensi: & ISSN 2252-7133 \\
Sekolah Menengah Pertama Negeri 1 Margahayu & E-ISSN 2548-4648 \\
E-mail: euisani.mhgy@gmail.com &
\end{tabular}




\section{PENDAHULUAN}

Proses belajar mengajar merupakan inti dari suatu proses pendidikan yang secara keseluruhan dengan guru sebagai pemegang peran utama dan penting. Suatu proses belajar mengajar menuntut untuk adanya perencanaan strategi tertentu, karena pada dasarnya strategi ini merupakan perancangan prosedur dan langkahlangkah yang akan ditempuh guna mencapai tujuan pembelajaran yang diinginkan.

Strategi yang telah ditentukan oleh seorang guru dalam proses belajar mengajar tidak terlepas dari pendekatan-pendekatan yang dilakukan oleh guru tersebut. Pendekatan disini lebih ditekankan pada pendekatan pembelajaran yang nantinya akan diterapkan dalam proses belajar mengajar. Pendekatan yang digunakan pun harus berlandaskan pada pengetahuan dan pemahaman serta keterampilan mengenai pendekatan pembelajaran yang akan digunakan.

Pada kenyataan dilapangan menunjukkan bahwa tingkat prestasi maupun sistem pembelajaran IPS masih belum maksimal. Hal ini terbukti dari hasil wawancara siswa yang sebagian besar menjawab bahwa mata pelajaran IPS sulit untuk dipelajari dan dipahami, selama kegiatan pembelajaran guru menilai bahwa keaktifan atau aktivitas belajar siswa didalam kelas masih kurang terlihat baik dan kurang efektif, sehingga suasana kelas terasa lebih individual saat guru melakukan Kegiatan Belajar Mengajar didalam kelas,

siswa tidak mempunyai keinginan untuk bertanya, begitu pula saat guru mencoba untuk menerapkan metode diskusi, hasilnya metode pembelajaran diskusi menjadi tidak aktif karena kurang terjadi interaktif antara penyaji dengan peserta diskusi. Selain itu pada saat diskusi berlangsung, peneliti melihat kurang terjadi kerjasama antar kelompok sehingga yang terjadi adalah adanya saling mengandalkan dan tergantung pada anggota kelompok yang mempunyai prestasi didalam kelas.

Begitu pula saat guru melakukan tes terhadap siswa untuk melihat dan mengukur sejauh mana peserta didik dapat menguasai dan memahami materi yang telah diberikan, hasilnya sebanyak $65 \%$ sebagian besar siswa belum mencapai kriteria ketuntasan minimum yang telah ditentukan oleh pihak sekolah.

Perlu adanya perbaikan dalam proses pembelajaran IPS, dimana guru harus menemukan suatu model atau metode yang sesuai dengan keadaan kelas tersebut. Salah satu model pembelajaran yang dianggap sesuai dengan keadaan kelas tersebut adalah model pembelajaran kooperatif dengan menggunakan salah satu tipenya yaitu model pembelajaran kooperatif tipe Think Pair Share (TPS) dengan pertimbangan bahwa model pembelajaran kooperatif tipe Think Pair Share (TPS) ini adalah suatu model pembelajaran yang didalamnya siswa terkondisikan untuk dapat menggali potensi dirinya secara optimal dalam melakukan aktivitas belajar sehingga ketuntasan belajar yang diharapkan dapat tercapai. Model Pembelajaran Kooperatif tipe Think Pair Share (TPS) dianggap menjadi salah satu jalan yang dapat membantu guru keluar dari permasalahan yang dikemukakan diatas, karena model pembelajaran kooperatif tipe Think Pair Share (TPS) ini merupakan pembelajaran yang menekankan kepada siswa agar siswa dapat beraktivitas belajar didalam kelas. Model Pembelajaran Kooperatif tipe Think Pair Share (TPS) dapat menciptakan suasana belajar dapat lebih menyenangkan dan lebih interaktif, sehingga para siswa akan lebih bersemangat dalam mengikuti pelajaran dan dalam proses belajar, selain itu untuk guru pun tidak terlalu sulit dalam mentransfer ilmu kepada para siswanya.

Model Pembelajaran Kooperatif tipe Think Pair Share (TPS) ini siswa dituntut untuk belajar secara aktif antara siswa yang satu dengan siswa yang lain. Di sini guru hanya mengarahkan, membimbing, dan menciptakan suasana yang lebih mudah untuk membuat peserta didik tertarik dan termotivasi untuk belajar, memahami, dan mengerti materi pelajaran yang diberikan oleh guru. Model Pembelajaran Kooperatif tipe Think Pair Share (TPS) dapat membuat peserta didik merasa termotivasi untuk mengulang pelajaran yang telah diberikan disekolah atau belajar sendiri tanpa harus selalu tergantung pada guru yang 
memberikan materi dan menjadi siswa yang aktif dikelasnya.

Konsep seperti yang diterangkan diatas, diharapkan penerapan Model Pembelajaran Kooperatif tipe Think Pair Share (TPS) ini dapat membuat siswa belajar secara mandiri, maupun bekerjasama dengan rekan - rekannya dalam proses belajar mengajar dan mereka akan merasa bersemangat dalam setiap proses pembelajaran serta proses penyelesaian tugas yang diberikan oleh para guru yang sedang mengajar.

\section{METODE}

Permasalahan dalam penelitian ini adalah penerapan model pembelajaran Kooperatif tipe Think Pair Share (TPS) pada mata pelajaran IPS di SMP Negeri 2 Katapang untuk meningkatkan Aktivitas dan Ketuntasan belajar Siswa. Penelitian ini bertujuan untuk memecahkan permasalahan dalam pembelajaran IPS. Oleh sebab itu metode penelitian yang digunakan adalah penelitian tindakan kelas (classroom action research). Makna yang terkandung dalam penelitian tindakan-tindakan tertentu agar dapat memperbaiki atau meningkatkan praktik pembelajaran yang pelaksanaannya dilakukan secara berulang-ulang.

Penelitian tindakan ini dimulai dengan studi pendahuluan yang dilakukan pada kegiatan pembelajaran sebelum nya kemudian dijadikan bahan refleksi untuk menentukan langkah kegiatan selanjutnya (tindakan, observasi, refleksi dan penyusunan rencana ulang) hingga tujuan penelitian tercapai.

Penelitian tindakan ini dilakukan pada jadwal mengajar yang proses pelaksanaan nya dilakukan secara bersiklus. Siklus ini tidak hanya berlangsung satu kali, tetapi beberapa kali hingga mencapai tujuan yang diinginkan, yakni perubahan perbaikan dalam pembelajaran IPS yang menjadi kepedulian penelitian ini.

Ada empat langkah penting dalam setiap siklus penelitian tindakan kelas, yaitu perencanaan (plan), pelaksanaan (act), pengamatan (observe), dan refleksi (reflect), dan tahap-tahap ini akan diulangi pada siklus berikutnya, dan seterusnya hingga siklus
terakhir.(Wiriaatmaja,2005:66). Tahapan yang dimaksud dijelaskan sebagai berikut:

1. Perencanaan, yaitu kegiatan yang dilakukan dalam menyusun rencana tindakan yang hendak dilaksanakan di kelas. Rencana disusun secara fleksibel, karena untuk mengakomodir berbagai kemungkinan yang dapat saja terjadi ketika tindakan dilaksanakan. Perencanaan disusun secara reflektif agar tindakan lebih terarah pada sasaran yang hendak dicapai, dengan didasari pada pertimbangan apakah tindakan yang akan dilaksanakan tersebut mungkin untuk dapat dilaksanakan secara efektif dalam berbagai situasi kelas.

2. Pelaksanaan (Tindakan). Yaitu kegiatan pembelajaran yang dilakukan berdasarkan rencana yang telah dibuat sebelumnya.

3. Observasi (Pengamatan), yaitu kegiatan mengamati, mengenali sambil mendokumentasikan (mencatat dan merekam) terhadap proses, hasil, pengaruh dan masalah baru yang mungkin saja muncul selama tindakan dilakukan. Hasil observasi ini akan dijadikan bahan analisis dan dasar refleksi terhadap tindakan yang telah dilakuakan.

4. Refleksi, yaitu merenungkan sambil mengevaluasi tentang apa-apa saja rencana dan tindakan yang sudah tercapai dan apa yang belum dapat dan sempat dilakukan pada suatu siklus. Berangkat dari hasil refleksi ini, peneliti merumuskan kembali rencana pembelajaran untuk ditindaklanjuti pada siklus berikutnya. Refleksi dilakukan pada tahap orientasi, proses, dan akhir program tindakan, yaitu:

a. Refleksi awal yaitu dilakukan pada saat orientasi terhadap permasalahanpermasalahan maupun faktor-faktor pendukung dan penghambat rencana penerapan model. Hal ini bertujuan untuk merumuskan proposisi awal terhadap situasi sosial dalam penerapan model yang akan dilakukan, kemudian hal tersebut dituangkan ke dalam suatu rencana awal rencana program tindakan yang akan dilakukan. 
b. Refleksi proses, yaitu refleksi yang dilakukan pada saat pelaksanaan program tindakan yang dimaksudkan untuk mengkaji proses, dan hasil serta implikasi dari program tindakan yang dilakukan terhadap perolehan hasil belajar siswa. Unjuk kerja guru dan siswa dalam pembelajaran, serta implikasi-implikasi lain yang berkembang selama pelaksanaan tindakan. Hal ini juga dilakukan untuk melakukan revisi terhadap rencana yang telah disusun dan sebagai dasar dalam merancang program tindakan selanjutnya dalam hubungannya dengan keterampilan sosial siswa pada pembelajaran portofolio IPS di SMP Negeri 2 Katapang.

c. Refleksi hasil, yaitu refleksi yang dilakukan pada akhir pelaksanaan program tindakan sesuai dengan rencana program tindakan yang telah ditetapkan dan fokus permasalahan serta tujuan pelaksanaan program tindakan. Artinya bahwa program pelaksanaan telah dipandang berhasil dan mendukung ketercapaian tujuan dari program tindakan yaitu setelah terjadinya peningkatan situasi belajar mengajar yang berorientasi pada upaya peningkatan proses dan hasil belajarsiswa, baik dilihat dari penguasaan materi, sikap dan keterampilan-keterampilan sosial, unjuk kerja guru, dan proses belajar mengajar dalam pembelajaran portofolio IPS di SMP Negeri 2 Katapang. Refleksi hasil ini pada dasarnya dimaksudkan untuk melakukan rekonstruksi dan revisi terhadaap penerapan pembelajaran portofolio IPS yang dikembangkan dalam program tindakan ini sesuai dengan tujuan pokok dari pelaksanaan tindakan.

Dalam penelitian ini, jumlah siklus yang dilakukan sebanyak tiga kali ketercapaian tujuan, berdasarkan pada rencana tindakan yang telah disusun atau dirumuskan sebelumnya.

\section{PEMBAHASAN}

Sebelum penerapan model pembelajaran Kooperatif Think Pair Share (TPS), peneliti terlebih dahulu menyusun Rencana Pelaksanaan Pembelajaran (RPP), lembar observasi, dan lembar tes formatif yang diberikan pada setiap akhir siklus serta lembar tes sumatif dan lembar angket yang diberikan pada akhir terlaksananya seluruh siklus.

Pada setiap siklus, guru sebagai peneliti melakukan observasi yang dibantu oleh seorang observer, hal ini dilakukan untuk mengetahui aktivitas siswa dan penerapan model pembelajaran kooperatif tipe Think Pair Share (TPS) pada setiap siklusnya selama proses pembelajaran berlangsung. Hasilnya dari siklus I sampai siklus III menunjukkan peningkatan, begitu pula yang terjadi pada penerapan model pembelajaran kooperatif tipe Think Pair Share (TPS) selama proses pembelajaran siklus I sampai siklus III berlangsung.

Menurut Abu Ahmadi dan Joko T.P (2015: 125) menjelaskan bahwa keaktifan siswa dalam proses belajar mengajar beraneka ragam seperti mendengarkan ceramah, berdiskusi, membuat suatu alat, membuat laporan pelaksanaan tugas dan sebagainya. Keaktifan siswa yang berbeda-beda itu dapatlah dikelompokkan atas aktivitas yang bersifat fisik dan non fisik seperti mental, intelektual, dan emosional. Dari materi tersebut diatas, maka dibuatlah lembar observasi untuk mengamati aktivitas siswa dan Penerapan Model Pembelajaran Kooperatif Tipe Think Pair Share (TPS). Observasi yang dilakukan oleh peneliti adalah untuk mengetahui aktivitas siswa dan penerapan model pembelajaran ini kedalam proses pembelajaran. Adapun aspek yang diamati dalam observasi aktivitas siswa adalah kegiatan visual, kegiatan oral, kegiatan mendengarkan, kegiatan menulis, kegiatan menggambar, kegiatan motorik, kegiatan mental, dan kegiatan emosional. Hasil penelitian menunjukkan aktivitas siswa pada setiap pembelajaran didalam kelas sebagian besar siswa 
mengikuti proses pembelajaran dengan baik, hasil observasi dapat dilihat pada hasil penelitian. Selain itu hasil pengamatan guru yang bersangkutan mengemukakan pendapatnya dalam hasil wawancara bahwa dengan menerapkan model pembelajaran kooperatif tipe Think Pair Share (TPS) siswa terlihat dapat memahami materi dengan seksama, dapat mengerjakan soal latihan secara individu, dapat bekerjasama dengan rekannya, dan dapat membuat suasana diskusi menjadi lebih efektif.

Selain itu, pada setiap siklus dilakukan sebuah tes formatif yang hasilnya mengalami peningkatan dengan rata - rata $84,7 \%$ dan untuk menutup seluruh siklus, peneliti melakukan sebuah tes sumatif dengan persentase ketuntasan adalah 84 \% . Menurut Ahmadi dan Joko T.P (2015: 157) bahwa maksud utama konsep belajar tuntas adalah usaha dikuasainya pelajaran oleh sekelompok siswa yang sedang mempelajari pelajaran secara tuntas. Persyaratan penguasan materi pelajaran bergerak antara $75 \%$ sampai dengan 90\%. Jika presentase ini belum tercapai maka siswa harus dibantu oleh guru disekolah sehingga mencapai penguasaan pada taraf yang sudah ditentukan. Batas minimum penguasaan ini kadang - kadang dijadikan dasar kelulusan bagi siswa yang mempelajari materi pelajaran tersebut. Berdasarkan materi diatas dan batas Ketuntasan Minimum yang telah ditentukan oleh organisasi sekolah, tes Fomatif dan tes Sumatif yang dilaksanakan sudah dikategorikan kedalam kategori "Tuntas", karena berada diantara 75\% sampai dengan $90 \%$ dan diatas $70 \%$.

Setelah dilakukannya tes sumatif, peneliti juga melakukan penyebaran angket untuk mengetahui sejauhmana tanggapan siswa mengenai aktivitas belajar siswa selama penerapan model pembelajaran kooperatif tipe Think Pair Share (TPS) pada pokok bahasan ekonomi kreatif berlangsung. Hasil pengolahan angket dapat diketahui bahwa interpretasi angket tersebut adalah berjumlah $74,7 \%$ tetapi oleh peneliti dibulatkan menjadi $75 \%$, sehingga hasil pengolahan interpretasi angket tersebut dapat dikelompokkan kedalam kategori Sebagian Besar, hal ini menunjukkan bahwa pada proses pembelajaran dengan menggunakan model pembelajaran Kooperatif tipe Think Pair Share (TPS) ini sebagian besar siswa dapat beradaptasi dan menerima penerapan model pembelajaran tersebut dalam upaya meningkatkan aktivitas belajar siswa, serta dapat mengikuti proses pembelajaran dengan baik. Jadi, jika diambil benang merah dari pembahasan hasil penelitian yang dilakukan, bahwa Penerapan Model Pembelajaran Kooperatf tipe Think Pair Share (TPS) dapat meningkatkan aktivitas belajar siswa dan membantu siswa mencapai Kriteria Ketuntasan Minimum yang telah ditetapkan sebelumnya serta cocok diterapkan pada pembelajaran pokok bahasan ekonomi kreatif. Hal ini dapat terlihat dari semakin meningkatknya nilai tes dan hasil observasi serta hasil pengolahan angket yang menunjukkan hasil yang baik.

\section{SIMPULAN}

Berdasarkan hasil pengamatan, analisis, dan pembahasan yang telah dipaparkan pada bab sebelumnya, maka peneliti dapat menarik kesimpulan bahwa penerapan Model Pembelajaran Kooperatif tipe Think Pair Share (TPS) yang dilaksanakan pada setiap siklus dilakukan sesuai dengan langkah - langkah serta pengembangannya berdasarkan teori yang ada, dan diperoleh rata - rata 85,6\% penerapan model pembelajaran kooperatif tipe Think Pair Share (TPS) ini baik untuk diterapkan dalam proses pembelajaran. Selain itu dari hasil angket menunjukkan bahwa $75 \%$ sebagian besar siswa memberikan respon yang positif terhadap Penerapan Model Pembelajaran Kooperatif tipe Think Pair Share (TPS). Hasil observasi selama 3 kali kegiatan pembelajaran dengan menerapkan model pembelajaran kooperatif tipe Think Pair Share (TPS) menunjukkan rata - rata aktivitas siswa meningkat sebanyak $69,2 \%$ dimana sebagian besar siswa dapat beraktivitas dalam proses pembelajaran didalam kelas baik secara individu, dengan pasangannya, dan pasangan lain. Hasil tes formatif dari 3 kali tindakan diperoleh rata - rata $84,6 \%$ dan tes sumatif diperoleh rata - rata $84 \%$ siswa mengalami ketuntasan belajar (dikatakan tuntas karena berada diatas penilaian acuan patokan sebanyak 
70). Model Pembelajaran Kooperatif tipe Think Pair Share (TPS) ternyata terbukti dapat meningkatkan aktivitas siswa dan membantu siswa untuk mencapai ketuntasan belajar dalam proses pembelajaran.

\section{DAFTAR PUSTAKA}

Ahmadi, A, dkk. 2015. SBM (Strategi Belajar Mengajar) untuk Fakultas Tarbiyah Komponen MKDK. Pustaka Setia: Bandung.

Arikunto, S. 2013. Dasar-Dasar Evaluasi Pendidikan (Edisi Revisi). Buni Aksara: Jakarta.

Arikunto, S, Suhardjono, Supardi. 2013. Penelitian Tindakan Kelas (Edisi Revisi). Bumi Aksara: Jakarta.

DEPDIKNAS. 2003. Sistem Pendidikan Nasional No. 20. Bp. Restindo Mediatama: Jakarta.

DEPDIKNAS. 2008. Penetapan Kriteria Ketuntasan Minimal (KKM).

Hamalik, O. 2015. Perencanaan Pengajaran Berdasarkan Pendekatan Sistem. Bumi Aksara: Jakarta.

Mulyasa, E. 2016. Menjadi Guru Profesional (Edisi Revisi) Remaja Rosda Karya: Bandung.
Nana, S,S. 2017. Metode Penelitian Pendidikan (Edisi Revisi). Program Pascasarjana Universitas Pendidikan Indonesia dengan Remaja Rosda Karya: Bandung.

Puwanto, N, M.P. 2016. Prinsip dan Teknik Evaluasi Pengajaran. Remaja Rosda Karya: Bandung.

Sardiman,A.M. 2014. Interaksi dan Motivasi Belajar Mengajar. Rajawali Pers: Jakarta.

Sudijono, A. 2016. Pengantar Evaluasi Pendidikan. Rajawali Pers: Jakarta.

Sudjana, N. 2015. Penilaian Hasil Proses Belajar Mengajar. Remaja Rosda Karya: Bandung.

Sutikno, M Sobry. 2008. Belajar dan Pembelajaran "Upaya Kreatif Dalam Mewujudkan Pembelajaran yang Berhasil". Prospect: Bandung.

Trianto. 2017. Model-model Pembelajaran Inovatif Berorientasi Konstuktivistik (Konsep, Landasan Teoritis - Praktis dan Implementasinya). Prestasi Pustaka Publisher: Jakarta.

Wiriatmadja, R. 2017. Metode Penelitian Tindakan Kelas Untuk Meningkatkan Kinerja Guru Dan Dosen. Program Pascasarjana Universitas Pendidikan Indonesia dengan Remaja Rosda Karya: Bandung. 